\title{
The Development of a Reflective Teaching Model for Reading Comprehension in English Language Teaching
}

\author{
Tun Zaw Ooa, Anita Habók,b
}

\author{
Received \\ Revised \\ Accepted \\ $\mathrm{DOI}$ \\ 12 Febraury 2020 \\ 2 June 2020 \\ 26 September 2020 \\ 10.26822/iejee.2020.178 \\ Tun Zaw Oo. Doctoral School of Education, \\ University of Szeged, Hungary. \\ E-mail: ootuzaw111@gmail.com \\ ORCID: http://orcid.org/0000-0002-7456-3709 \\ ${ }^{\mathrm{b}}$ Corresponding Author: Anita Habók. \\ University of Szeged, Hungary. \\ E-mail: habok@edpsy.u-szeged.hu \\ ORCID: http://orcid.org/0000-0003-0904-8206
}

\begin{abstract}
The main objective of the paper is to develop a Reflective Teaching Model for Reading Comprehension (RTMRC) in English Language Teaching (ELT). In recent decades, the concept of 'reflection' has become widely used in relation to an effective teaching process in various contexts, such as reflective teaching, reflective practices, reflective inquiry, self-observation, self-evaluation, and peer review. Although it is widely accepted in terms of use, the notion of 'reflection' is still broad and confusing, since it has different meanings and is used diversely in various areas of education. Thus, the first part provides an overview of the numerous perspectives in different research fields on the concept of reflective teaching in ELT reading comprehension, which contribute to the analysis, synthesis, and summary of RTMRC. In the second part, an evaluation of researchers' perspectives in teaching methodology and English language teaching is provided. We have concluded that our summary model based on the literature review is suitable as an instructional framework for ELT practitioners during the teaching process. Moreover, our review indicates that the stages of RTMRC that have been identified are appropriate for use in teaching and learning reading comprehension.
\end{abstract}

\author{
Keywords: \\ Reflective Teaching, Reading Comprehension, \\ English as a Foreign Language.
}

\section{Introduction}

The concept of 'reflection' has a decades-long history of use. Almost a century ago, John Dewey (1933) had already applied the concept of 'reflection', 'reflective thought', and 'reflective thinking'. Dewey (1933) emphasized the relationship between learning and reflection and indicated that learners should reflect upon their professional actions and their consequences (Pacheco, 2005; Richardson, 1990). Richards (1990, p. 1, cited in Edwards, 2017) stated that reflection or critical reflection involves an activity "in which an experience is recalled, considered, and evaluated." Reflection is an important learning component for both 
learners and teachers (Habók \& Magyar, 2018a, 2018b, 2019). Pacheco (2005) also indicated that reflection and reflective learning have more positive effects on learning that underline the importance of developing and using reflective practices.

However, many teachers have misconceptions about reflection, for example, that 'reflection' means 'just thinking' and 'simple thinking' about the teaching and learning process. Paterson and Chapman (2013) prepared a precise description of the reflective practice to interpret reflective teaching and learning practices more clearly. They established that reflection not only includes a simple overview and description of a learner's activity, but rather requires cognitive and metacognitive activities in which the learner recognizes what has been learned, mobilizes his/ her prior knowledge, and connects new information to existing information. It also comprises affective and metacognitive activities, which help the learner to evaluate his/her emotions and enthusiasm. This interpretation also requires a conscious teaching activity from teachers.

This study is intended to examine various studies of reflective teaching and to compare them as well as to discover possible distinctions. By considering gaps and distinctions in various studies, a summary of a new Reflective Teaching Model for Reading Comprehension (RTMRC) will be created to provide instruction in reading comprehension in English Language Teaching (ELT).

\section{Review of Related Literature}

\section{Criteria for the Development of the Teaching Model}

A model is a design of practical procedures that can be used in teaching school children to achieve their desired goals (Akyol, Çakıroğlu, \& Kuruyer, 2014; Ghilay \& Ghilay, 2015; Habók 2012). Richey and Seels (1994, cited in Joyce, Weil, \& Calhoun, 2015) stated that the term 'model of teaching' means preparing a plan that can form the basis for the teaching design and developing teaching materials in the classroom environment or other settings. Borich (2014) also highlighted that an educational model can include instructional specifications combined with instructional theory and learning practice, thereby ensuring the quality of education. In this process, the focus is on an analysis of learning goals and needs, and the goal is to monitor the teaching and learning process and to meet emerging needs. To elaborate on an instructional design like this, Gustafson and Branch (2002) summarized a variety of traditional instructional design models. The models they described stress such components as analysis, design, development, implementation, and evaluation.
However, Reiser and Dempsey (2012) underlined some criteria that should be involved in all instructional design models. They pointed out that instructional design should fulfil the following criteria: it has to (1) be student-centered; (2) be goal-oriented; and (3) be focused on meaningful performance; as well as (4) be ensure the assessment of the validity and reliability of outcomes; (5) be empirically measurable and make self-correction possible; and (6) allow for a team effort. Based on these criteria, the authors attempted to develop an RTMRC for the instruction of reading comprehension in ELT.

\section{Components of Reflective Teaching}

As previously noted, reflection and reflective teaching are interpreted in a broad sense. A study by Ashwin, Boud, and Coate, et al. $(2015,266)$ described reflective teaching using Dewey's ideas, according to which "reflection is the active, persistent, and careful consideration of any belief or supposed form of knowledge in the light of the grounds that support it and the further conclusion which it tends". They also pointed out the key component of reflective teaching, namely, systematic re-evaluation of the teaching experience when necessary to change teaching practices. Spalding and Wilson (2002) defined reflective teaching as "an activity or process in which an experience is recalled, considered, and evaluated, usually about a broader purpose" (Spalding \& Wilson 2002, 1394).

Implementing reflective practices is based on both present and past teaching activities. To underline this fact, Donald Schön's study (1983) indicated two kinds of reflective practices, reflection-on-action, and reflection-in-action. Reflection-on-action means carefully re-thinking previous teaching and learning activity. The emphasis is on evaluating one's own strengths and weaknesses to develop more effective approaches in a situation. Reflection-in-action involves monitoring and assessing one's own and others' behavior in teaching and learning events (cited in Edwards, 2017).

Cirocki and Farrelly (2016), in turn, also established the nature of reflective teaching and distinguished between three types of reflection such as content reflection (what), process reflection (how), and premise reflection (why). Furthermore, Senge (1990, cited in Taggart \& Wilson, 2005) identified three types of reflection; (1) technical reflection, (2) practical reflection, and (3) critical reflection. Technical reflection in education includes a reflection on teaching strategies, techniques, and skills. This type is related to Schön's reflection-on-action types and focuses on the questions the teacher asks: What did I implement? How can I teach more effectively? Practical reflection 
highlights concentration on professional practice, what it means, and why it is important. Critical reflection unites the previous two levels of reflection. In addition, it contains a reflection on the teaching context in the broadest sense, including political, financial, and ethical factors.

In some studies (Graves, 2002; Fatemipour, 2013), reflection is a significant tool for teachers. It helps to explore, understand, and reconsider their teaching practice. Reflection means not only seeing and recognizing, but also understanding teaching and learning processes. Brookfield (2017) indicated in his study that the meaning of reflective teaching combines a wide range of practices, such as teaching inventories, observation checklists, self-evaluation scales, and students' evaluation tools. From the perspective of the reflective teaching process, he pointed out four sources that can be used by teachers for an effective reflective teaching process. The teachers can decide if they will use one or more of the sources. These are students' views, teacher colleagues' perceptions, personal experiences, and/ or theoretical research.

Richards and Lockhart $(2005,4)$ noted that reflective teaching denotes a process which generally describes how the teacher teaches in the classroom and what kinds of methods they apply; they viewed as "the ongoing process and a routine part of teaching, it enables teachers to feel more confident in trying different options and assessing their effects on teaching". They also indicated that it is a cyclical process in which the teacher moves from one teaching stage to the next to fully grasp how they matter in the classroom situation. Additionally, they introduced reflective teaching as an action plan which comprises the following components: planning, action, observation, and reflection. Richards and Lockhart (2005) clearly stated that "their book does not set out to tell teachers what effective teaching is, but rather tries to develop a critically reflective approach to teaching, which can be used with any teaching method or approach" (Richards and Lockhart 2005, 3). According to them, therefore, reflective teaching can be applied together with several teaching methods and strategies to support students' learning.

Hulsman, Harmsen, and Fabriek (2009) also regarded reflective teaching as the cyclical process of acting, observing, analyzing, presenting and feedback. In their research on medical students, they used this cyclical structure with the observational approach. Babaei and Abednia (2016) examined the connection between reflective teaching and English language teachers' self-efficacy beliefs. In their reflective teaching process, they agreed with Calderhead (1989, 43) that "reflective teaching involves critical inquiry, analysis, and self-directed evaluation".

Other researchers, such as Dewey (1933) and Schön (1983), also explored a cyclical structure of reflective thinking. In their conception, the first stage is to identify a problem. The next stage is to go back to the root of the problem and examine it from the perspective of a third person. Based on this step, we decide if the problem needs to be changed. In this stage, the following activities are required: observation, reflection, data collection, and consideration of moral principles. The next stage is evaluation, which refers to a review of the implementation of the process, its consequences, and outputs. The next stage in the cyclical structure can be acceptance or rejection of the final solution (Taggart \& Wilson, 2005).

Quite a few years ago, Kolb (1984, cited in Dennison, 2009) also carried out an experiment in teaching with his model of reflective teaching and confirmed the cyclical structure of learning and teaching. He identified four main parts of the reflective teaching process: (1) experience that we gained in the past or the present; (2) observation, which records what happened during the teaching event; (3) reflection, which involves defining, analysing, and concluding; and (4) planning, which makes it possible to make plans for further action.

In one distinct study (Pollard, Black-Hawkins, \& Hodges, et al., 2014), it was mentioned that reflective teaching is a cyclical process where teachers monitor, evaluate, and revise their teaching practice continuously. In line with this view, reflective teaching can also be defined as "A systematic self-evaluation cycle conducted by teachers toward their teaching through an open discussion with colleagues or written analysis. Since it is a cyclical process, the teachers should monitor, reflect, evaluate and revise their practice constantly to meet the high standard of teaching" (Ratminingsih, Artini, \& Padmadewi, 2018, 170).

Reflective teaching is defined by Farrell (2007) and Garzon $(2018,75)$ as "the process of teachers" consciously subjecting their beliefs about teaching and learning to critical analysis, assuming their responsibility in the classroom, and engaging in a process of improving teaching practices". KennedyClark, Eddles-Hirsch, and Francis, et al. (2018) also emphasized the role of observation, engagement, and beliefs. According to their theory, "reflective practice is a process of learning that occurs through observation and engaging in discussion of practice so that questions about tacit beliefs and pedagogical 


\section{iejee $\approx$}

practices could be examined" (Kennedy-Clark et al, 2018, 43). Apart from those researchers, Clarke (2008) based on earlier studies also conducted observational research in mathematics in the southern United States. In his conception of the reflective teaching process in the field of mathematical problem solving, he used three phases, understanding, planning, and looking back, which refer to a circular process.

\section{Distinctions from the Above Studies of the Components of Reflective Teaching}

Thus, based on the above studies, two main points can be highlighted: the nature of reflective teaching and the reflective teaching process. In the nature of reflective teaching, several key components can be identified:

- Reflective teaching is taking a conscious look at actions with emotions and enthusiasm to achieve higher-level understanding. For this definition of reflective teaching, these authors (Ashwin, et al., 2015; Edwards, 2017; Fatemipour, 2013; Graves, 2002; Spalding \& Wilson, 2002) applied the word, "reflection' in different ways; a conscious look, persistent and careful consideration, systematic re-evaluation, recalled and considered, rethinking, monitoring, and reconsider.

- Reflective teaching is based on both present and past events for effective learning. These studies (Edwards, 2017; Taggart \& Wilson, 2005) used this nature of 'reflection on present and past events' in different ways; reflection-onaction and reflection-in-action, and identify a problem and go back to the root.

- Reflective teaching is a cyclical process. These researchers (Clarke, 2008; Dennison, 2009; Dewey, 1933; Hulsman et al., 2009; Kolb, 1984; Pollard, et al., 2014; Ratminingsih, Artini, \& Padmadewi, 2018; Richards \& Lockhart, 2005; Schön, 1983; Taggart, \& Wilson, 2005) applied the term, 'cyclical process' in different ways; ongoing process and routine work, cyclical structure, systematic self-evaluation cycle, and circular process.

- In reflective teaching, various teaching methods and strategies can be applied and examined to help students learn more effectively (Kennedy-Clark, et al., 2018; Richards \& Lockhart, 2005).

In the case of reflective teaching process, various researchers have put forward different approaches to the reflective teaching process. However, these approaches have common objectives in that they are designed to re-evaluate teaching experiences systematically to change teaching practices. It is also clear that these researchers had different approaches to their different fields. Among their approaches, there are four common components: planning (consideration and thinking), acting (experience, practices, response, involvement in a scenario, and learning), reflecting (observation, review, recollection, documenting what happened, and recording the scenario), and evaluating (determination, interpretation, and assessment). These four components are more common than other stages of the reflective teaching process. These factors are presented in Table 1 in a comparison of the different researchers' reflective teaching stages.

\section{Conceptual Components to the Reading Comprehen- sion Process}

We now highlight certain research to present the theoretical background to the conceptual alternatives to the reading comprehension process. Various authors have pointed out that reading comprehension is a complex process during which readers use a number of mental processes, such as reading words, creating meanings, organizing the text, and applying strategies (Habók \& Magyar, 2018; Käsper, Uibu, \& Mikk, 2018; Rastegar, Kermani, \& Khabir, 2017). Kusumawati

Table 1. Comparison of various authors' reflective teaching stages in the reflective teaching process

\begin{tabular}{ccccc}
\hline & & & Reflective teaching process \\
\cline { 2 - 4 } Authors & Planning & Acting & Reflection & Analysis \\
\hline Taggart \& Wilson (2005) & $\checkmark$ & $\checkmark$ & $\checkmark$ \\
\hline Richards \& Lockhart (2005) & $\checkmark$ & $\checkmark$ & $\checkmark$ \\
\hline Clarke (2008) & $\checkmark$ & $\checkmark$ & $\checkmark$ \\
\hline Dennison (2009) & $\checkmark$ & $\checkmark$ & $\checkmark$ \\
\hline Hulsman, et al. (2009) & $\checkmark$ & $\checkmark$ & $\checkmark$ \\
\hline Pollard, et al. (2014) & $\checkmark$ & $\checkmark$ & $\checkmark$ \\
\hline Babaei \& Abednia (2016) & $\checkmark$ & $\checkmark$ & $\checkmark$ \\
\hline Garzon (2018) & $\checkmark$ & $\checkmark$ & $\checkmark$ \\
\hline Kennedy-Clark, et al. (2018) & $\checkmark$ & $\checkmark$ & $\checkmark$ \\
\hline
\end{tabular}


and Widiati $(2017,175)$ noted that "comprehension is a bridge between the known and the unknown". They also emphasized that comprehension is something that humans do from the early years. In an effort to comprehend information, they stated that the reader must relate his/her new information to his/her prior knowledge. Connors-Tadros $(2014,2)$ pointed out that "reading is an active and complex process that involves: (a) understanding written text, (b) developing and interpreting meaning, and (c) using meaning as appropriate to the type of text, purpose, and situation". Additionally, Gilbert $(2017,181)$ claimed that "reading in both first and second language context includes the reader, the text, and the interaction between the reader and the text". Reading comprehension is also defined by Lim, Eng, and Mohamed, et al. $(2018,146)$ as "a cognitive process that takes place when an individual interacts with the text".

According to Nordin, Rashid, and Zubir, et al. (2013, 469) "comprehending a text is an interactive process between the readers' background knowledge and the text itself". They divided this process into two parts: (1) the bottom-up approach to reading and (2) the topdown approach to reading. Baker and Boonkit (2004) observed that reading is also a process of bottom-up, top-down, and interactive approaches. To understand these three processes, Khaki $(2014,187)$ also identified three approaches to teaching these processes in the interaction approach; according to him, the students choose, based on the situation, which process (bottom-up or top-down) is more appropriate for them. For example, if the reader has background knowledge of the text, the top-down approach is more appropriate; however, if he/she does not have sufficient background knowledge, the bottom-up approach is more beneficial; the interaction approach is the most common in the language teaching classes if there are both types of readers (who have sufficient background knowledge, and who do not have such kind of knowledge) in the class.

Heilman, Blair, and Rupley (1986, cited in Suwanto, 2014) identified three levels of reading comprehension for English language teachers providing instruction on reading comprehension; (1) literal, (2) interpretative, and (3) critical comprehension. Literal comprehension highlights that a reader explicitly understands the key information in the text. Interpretative comprehension means that the reader can analyse and evaluate the text, and can personally react to ideas in the text. Critical comprehension requires that the reader can react critically to text information and form his/ her own opinion of it. These three levels are of great importance for students' reading comprehension and the evaluation of students' achievement.
Apart from these definitions of and approaches to reading comprehension, reading events can also be considered. Widdowson (2015) described which factors affecting a reading event can influence reading comprehension. These include the reader's background and prior knowledge, quality of reading materials, and type of teacher and text instructions. According to Yang (2016), the factors which affect strategies for developing reading comprehension can be divided into two dimensions: situational and individual. The situational dimension includes classroom settings, teaching methods, and reading texts. The individual dimension can be influenced by readers' age, motivation, learning strategies and style, personal circumstances, and certain other latent factors.

Fitrisial, Tan, and Yusuf $(2015,17)$ also listed the individual, task, and strategy as factors that influence reading events. They noted that 'person' means the reader whose general knowledge, age, aptitude, and learning strategies and styles are included in the learning process. 'Task' indicates all kinds of activities in which the reader must engage during the teaching session. Finally, 'strategy' involves an awareness of strategy use to interpret the text, e.g. how to select key information and main ideas, and how to predict the message of the text.

In his study, Staden (2010) also pointed out that there are only three main events affecting students' reading comprehension process. (1) Learner factors involve learner motivation, needs, opinions, values, relationships to peers, etc. (2) Home factors refer to parents' education, social relations, socio-economic status, etc. (3) School factors indicate teachers' characteristics, the structure of the education system, school facilities, etc.

Huang (2013, 151) identified certain factors that motivate students' reading as follows: cultural values, instructional methods, and structures in the school environment. Snow (2003) also characterized reading comprehension as an interactive process of deducing and constructing meaning from the text. This process involves three components: first, the reader who is reading and is involved in the comprehension process; second, the text that had to be processed and comprehended; and, third, the activity in which the reader is engaged during the comprehension process. These three significant components of reading comprehension proceed within a social context.

Zhang $(2016,132)$ also identified three variables, which influence reading and reading success. These are (1) text characteristics; (2) reader/viewer characteristics; and (3) social context. Another study (Walker, 2008) 


\section{iejee}

also indicated that there are five factors of the reading event, which must be taken into consideration during teaching. These are text, reader, task, teaching technique, and teaching context. These factors do not act separately but affect one another in teaching and learning. Walker (2008) also emphasized the notion of the 'context' in which environment the teaching has been implemented. Its role cannot be analyzed separately, since it is closely related to other factors, such as text, reader, task, teaching techniques, and context. Then, Suwanto (2014) also stated that a reader's understanding of the text depends on his/ her prior knowledge, skills, thinking ability, strategies, observations, the readiness of facilities, and the text objective. In addition, Suwanto (2014) stressed that understanding only depends on readers' sociocultural background.

Zhang and Zhang $(2013,37)$ indicated that "reading is a constructive process in which the text, the reader, and the context interact". In this process of interaction, the reader can reconstruct the information in the text based on his/her ability to decode and working memory based on his/her schemata. Thus, both the reader and the text can be considered as the main parts of the teaching-learning context.

\section{Distinction from the Above Studies of Reading Comprehension Process}

To conclude these research findings on the reading comprehension process, some concepts can be highlighted in two main categories: reading comprehension and factors affecting reading events. On the whole, two important perspectives on reading comprehension can be identified as follows.

- Reading comprehension is an interactive process between the reader and the text. These studies (Gilbert, 2017; Lim, et al., 2018; Nordin et al, 2013) described this interactive process in different ways; interaction between the reader and the text, individuals interact with the text, and interactive process between the reader's background knowledge and text itself.

- Reading comprehension is the relationship between known and unknown information. These studies (Khaki, 2014; Kusumawati \& Widiati, 2017; Snow, 2003; Suwanto, 2014) showed this type of relation into different ways; interactive process of deducing and constructing meaning from the text, interaction approach between top-down and bottom-up, and understanding only depends on readers' socio-cultural background.

Some common key components emerge from among the factors affecting the reading event described by various researchers. Although it is difficult to count all the factors affecting students' reading comprehension, the most common factors that can be reflected by teachers during instruction are strategy, text, task, reader, and context. In the case of context, some authors, such as Snow (2003), Staden (2010), Suwanto (2014), Yang (2016), and Zhang (2016), describe 'context' as a kind of readers' socio-cultural context. However, other authors, such as Walker (2008) and Zhang and Zhang (2013), found that the context indicates the instructional context. The most common issues of these two kinds of contexts show that the reader, text, strategies, and task are involved in the cases of these two kinds of contexts. These factors are also summarized in Table 2 in a comparison of the different authors' views. These factors in reading comprehension are also to be considered as the main factors that can be reflected during the instruction process for reading comprehension.

\section{Development of the Reflective Teaching Model for Reading Comprehension}

To conclude the conceptual alternatives of reflective teaching described above, first, the most distinct factor described by almost all the researchers in reflective

Table 2. Comparison of various researchers' views on the factors affecting the reading event

\begin{tabular}{|c|c|c|c|c|c|c|}
\hline \multirow{2}{*}{ Authors } & \multicolumn{6}{|c|}{ Reflective teaching process } \\
\hline & Teacher & Strategy & Reader & Task & Text & Context \\
\hline Snow (2003) & & & $\checkmark$ & $\checkmark$ & $\checkmark$ & $\checkmark$ \\
\hline Walker (2008) & & $\checkmark$ & $\checkmark$ & $\checkmark$ & $\checkmark$ & $\checkmark$ \\
\hline Staden (2010) & $\checkmark$ & $\checkmark$ & $\checkmark$ & $\checkmark$ & $\checkmark$ & $\checkmark$ \\
\hline Zhang \& Zhang (2013) & & & $\checkmark$ & & $\checkmark$ & $\checkmark$ \\
\hline Suwanto (2014) & & $\checkmark$ & $\checkmark$ & $\checkmark$ & $\checkmark$ & $\checkmark$ \\
\hline Fitrisial, Tan, and Yusuf (2015) & $\checkmark$ & $\checkmark$ & $\checkmark$ & & $\checkmark$ & \\
\hline Widdowson (2015) & & $\checkmark$ & $\checkmark$ & & $\checkmark$ & \\
\hline Yang (2016) & $\checkmark$ & $\checkmark$ & $\checkmark$ & $\checkmark$ & $\checkmark$ & $\checkmark$ \\
\hline Zhang (2016) & & & $\checkmark$ & & $\checkmark$ & $\checkmark$ \\
\hline Gilbert (2017) & & & $\checkmark$ & & $\checkmark$ & \\
\hline
\end{tabular}


teaching (Ashwin, et al., 2015; Cirocki \& Farrelly, 2016; Fatemipour, 2013; Garzon, 2018; Hulsman, Harmsen, \& Fabriek, 2009; Pollard, et al., 2014; Ratminingsih, Artini, \& Padmadewi, 2018; Richards \& Lockhart, 2005; Spalding \& Wilson, 2002; Taggart, \& Wilson, 2005) is that reflective teaching is a cyclical and conscious process. Therefore, a teacher who uses reflection should know the main concepts of this process. Second, considering what distinct stages from Table lare to be included in this process, various researchers have consistently described four main stages in this process: planning, acting, reflecting, and evaluating (see Fig. 1).

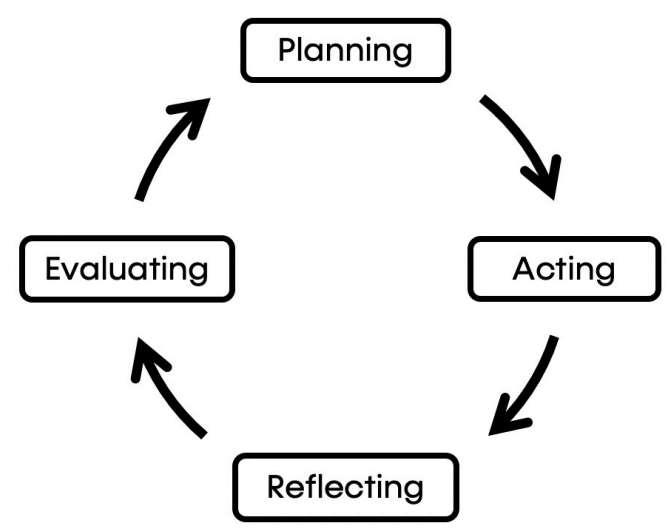

Figure 1. The reflective teaching process

In the conclusion of the reading comprehension process, according to these researchers, the first main idea is that reading comprehension is a process in which the reader interacts with the text. Actually, in the reflective teaching process related to students' reading comprehension, merely reflecting on the reader and text is not sufficient. Therefore, the second main idea is that five distinct main factors affect students' reading comprehension process, according to the researchers. These are listed in Table 2. These are context, strategy, reader, task, and text. The third main idea is that the notion of 'context', where instruction occurs as a kind of instructional context, is interconnected with other factors, such as task, reader, text, and strategy. To reconfirm the role of this third concept, Walker (2008, 28-31) also stated that context, which proceeds during the teaching event, plays a key role in influencing learning. She highlighted some important factors to be considered during the teaching context. These are the teaching strategy (teacher's methodology), organization work while completing the reading task (group work, pair work, individual work, and scheduling), text (source of information), and reader's characteristics (prior knowledge and previous experiences in learning situations). Therefore, the structure of these three components is visualized in Fig. 2.

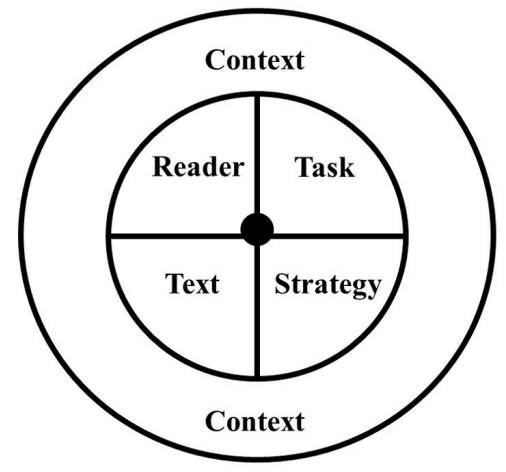

Figure 2. Factors in the reading event

Based on a number of studies (Ashwin, et al., 2015; Cirocki \& Farrelly, 2016; Fatemipour, 2013; Garzon, 2018; Hulsman, Harmsen, \& Fabriek, 2009; Richards \& Lockhart, 2005; Spalding \& Wilson, 2002; Taggart, \& Wilson, 2005), reflective teaching is used in different fields such as mathematics, English language teaching, dance education, and the sciences. Therefore, to apply the reflective teaching process in teaching reading comprehension, the teacher can construct a new RTMRC and conduct experimental research to test it. Richy and Seels (cited in Joyce, Weil, \& Calhoun, 2015) stated that the model of teaching consists of planning and designing teaching materials and implementing teaching in the classroom environment or in other settings. Therefore, to be able to construct a reflective teaching model, the previously mentioned two summaries (reflective teaching process and factors in the reading event) can be integrated into the teaching design of the reflective teaching in the reading comprehension process. On the whole, a tentative Reflective Teaching Model for Reading Comprehension (RTMRC) can be created as shown in Fig. 3.

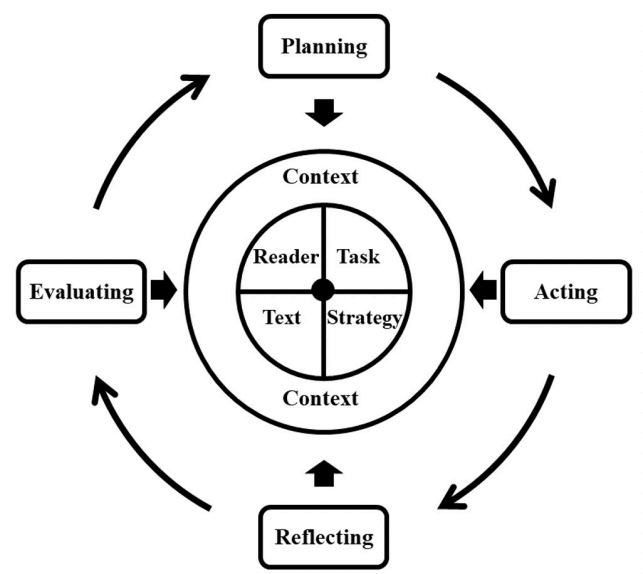

Figure 3. Reflective Teaching Model for Reading Comprehension

Four main components are involved in this reflective teaching model: planning, acting, reflecting, and evaluating. According to Richards and Lockhart (2005, 
28), in the planning stage, the teacher can plan the factors before the teaching session. For example, who is going to do what activities (reader and task)? How does the teacher intend to implement his/her revised teaching strategies (strategy)? What are the changes to the curriculum (text)? To monitor these components, the teacher can develop questionnaires or apply other methods, e.g. prepare a self-evaluation questionnaire to monitor his/her own reflection on the teaching process.

In the acting stage, the teacher can execute the previous planning parts. In the reflecting stage, Richards and Lockhart (2005) also highlighted those teaching events will rarely go precisely as expected in implementing the plan. The most important factor in this stage is to make certain to record any deviations from the plan and the reason why they have occurred. The teacher can use a structured students' questionnaire as one of the reflecting pools to reflect on what has happened during the teaching-learning process (Brookfield, 2017; Habók \& Magyar, 2018a; Habók \& Magyar, 2018b).

In the evaluating step, the last point of the cycle, Richards and Lockhart (2005) also suggested that the teacher can evaluate two factors: the teaching and learning process and students' achievement. To evaluate the teaching and learning process, the teacher can review the questionnaires that are applied in the reflecting stage. After evaluating the questionnaire, the teacher can think about what actions (strategy/task/reader/text) are to be changed for the next lesson. As regards evaluation, the teacher can assess students' achievement at the end of the learning session or unit.

\section{Researchers' Perceptions of the Reflective Teaching Model for Reading Comprehension (RTMRC)}

We applied two levels to develop Reflective Teaching Model for Reading Comprehension (RTMRC). In the first level, various authors' conceptual alternatives of reflective teaching and reading comprehension were reviewed, analyzed, synthesized, and summarized to develop a new tentative RTMRC design for ELT. In the second level, the evaluation form of this tentative RTMRC design and its related reviewed descriptions were sent to experts in teaching methodology and English language teaching for evaluation. Criteria developed by Reiser and Dempsey (2012) were used to evaluate the effectiveness of the RTMRC.

In this stage of evaluation, an evaluation form which was adapted from Nguyen and Suppasetseree (2016) was developed by the researchers. This evaluation form is also based on the instructional design criteria of Reiser and Dempsey (2012) mentioned above. There are two main parts in this form. In the first part, a fourpoint Likert scale (1 = Strongly Disagree, 2 = Disagree, 3 = Agree, 4 = Strongly Agree) was used. In the second part, a list of open-ended questions was attached to monitor participants' thoughts and opinions on the developed model, after which the RTMRC was reconstructed on their recommendations similar to the research of Nguyen and Suppasetseree (2016). The results were grouped into three main levels to evaluate the efficacy of the RTMRC on reading comprehension.

We examined means and standard deviations using descriptive statistics. In case where the mean of the evaluation list ranges from 1.00 to 2.00 , it indicates that the RTMRC is less appropriate, according to the experts' opinion. If the mean is between 2.01 and 3.01, it also reveals that the RTMRC is appropriate. According to our interpretation, if the mean falls between 3.02 and 4.00, it indicates that the RTMRC is the most appropriate. Table 3 presents the results of experts' opinion.

Based on these findings, items 1, 3, 4, 5, 8, and 10 have slightly lower means, and items 2, 6, 7, and 9 have the highest mean scores. However, this is not a great problem, as all mean scores for these items

Table 3. The Results of Experts' Evaluation on the Development of RTMRC

\begin{tabular}{|c|c|c|c|}
\hline No & Item & Mean & SD \\
\hline 1 & Step 1, Planning is appropriate. & 3.50 & .58 \\
\hline 2 & Step 2, Acting is appropriate. & 4.00 & .00 \\
\hline 3 & Step 3, Reflecting is appropriate. & 3.00 & .00 \\
\hline 4 & Step 4, Evaluating is appropriate. & 3.00 & .00 \\
\hline 5 & The steps in the RTMRC are clear and easy to implement. & 3.75 & .50 \\
\hline 6 & The outcomes can be measured in a valid and reliable way. & 4.00 & .00 \\
\hline 7 & The RTMRC is empirical, iterative, and self-correcting. & 4.00 & .00 \\
\hline 8 & Each element of the RTMRC is linked to another element. & 3.75 & .50 \\
\hline 9 & The RTMRC can facilitate student-student interaction. & 4.00 & .00 \\
\hline \multirow[t]{2}{*}{10} & The RTMRC has sufficient capacity to be able to teach students' reading comprehension. & 3.25 & .50 \\
\hline & Total & 3.60 & .50 \\
\hline
\end{tabular}


are above 3.02 (based on the above criteria for the effectiveness of the RTMRC from Table 3). Thus, it can be interpreted that all the steps in the RTMRC design are highly appropriate for providing instruction in reading comprehension in ELT, according to the experts. In addition, all the experts agree that: (1) the steps in the RTMRC are clear and easy to implement in a classroom environment; (2) the outcomes can be measured in a valid and reliable way; (3) the RTMRC makes self-correction possible; (4) each element of the RTMRC is linked to another element;(5) the RTMRC can facilitate student-student interaction; and (6) the RTMRC has sufficient capacity to be able to teach students' reading comprehension.

\section{Discussion}

This study aimed to develop an RTMRC for ELT. We, therefore, reviewed various studies on reflective teaching and reading comprehension. These theoretical approaches were analysed, synthesized, and interpreted. After that, we elicited the opinion of four experts for a model. As the results showed, all the components may be involved in the teaching model. The literature review and experts' responses confirmed that the RTMRC was appropriately designed based on the criteria for instructional design developed by Reiser and Dempsey (2012).

In the RTMRC, the theory of constructivism is involved in focusing on students' understanding, processing, and evaluating of the reading text. The RTMRC is studentcentered, teamwork-oriented, and easy to implement in teaching students' reading comprehension skills.

We concluded that the four main stages can be identified. In stage 1, planning, the teachers need to plan and consider who, what, and how to teach, as well as why. This stage can be applied by preparing the lesson plan to teach reading comprehension. In this stage, the teacher can plan to use the different kinds of teaching strategies for reading comprehension and student-centered learning. In stage 2 (acting), the teacher can teach based on his/her planning. In stage 3 (reflecting), for the reflection on the text (a text which has been taught), the teacher can ask the students some reflective questions after teaching with one strategy. The teacher can also reflect on his/her teaching based on strategy, reader, task, and text. In this kind of reflection, the teacher can reflect on the reader, task, and strategy using a students' preference questionnaire. This type of questionnaire can be distributed to the students after using one strategy type in the class. Therefore, stage 3 is also appropriate for teachers. In stage 4 (evaluating), the teacher must evaluate the reflected data from the students' preference questionnaire and the reflective questions after instruction. Therefore, it can be interpreted that this RTMRC has sufficient capacity to form the basis for teaching students reading comprehension.

It should be pointed out that this is a pre-assessment of the appropriateness of the RTMRC for teaching reading comprehension. We are aware of the low sample number, but seeing experts' opinions was important at this stage. All the experts confirmed that the RTMRC is logical and appropriate for teaching ELT reading comprehension. Therefore, later, the researchers can do experimental research on the effect of the RTMRC design on students' achievement in this area.

\section{Pedagogical Implications}

First, in the stage of planning, the teacher must plan the lessons based on text, strategy, reader, and task. However, he/she should especially consider which reading strategy is the most appropriate for his/her students or class, how to analyze students' needs, how to reflect on his/her actions in the class, and how to evaluate the reflected data for his/her progress. Only when teachers can plan successfully, the further stages of the RTMRC will be easier for them. Second, the RTMRC is highly transparent and supportive not only for teachers but also for their students in reading comprehension. As this RTMRC seems to be one of the most basic and systematic instructional designs, it may be beneficial for the education system and its participants.

\section{Conclusion}

This paper has developed the RTMRC by reviewing different researchers' perspectives on the concept of reflective teaching in ELT reading comprehension. To conclude this paper, two main parts can be found: What are the different authors' conceptual alternatives in reflective teaching in ELT reading comprehension? What are the results of four experts' evaluations on the RTMRC design? For the different researchers' concepts on the RTMRC, we pointed out different research perspectives to compare the similarities and differences among them.

Reviewing the different researcher's perspectives on the reflective teaching process, we found that there were different conceptual, theoretical, and practical factors. Then we deduced a summarized conceptual reflective teaching process which involves four main components: planning, acting, reflecting, and evaluating. These factors are only for the reflective teaching process. Therefore, we looked for perspectives on how to use this reflective teaching process in the area of students' reading comprehension in ELT. 


\section{iejee}

We identified certain factors on students' reading comprehension process and then sought to determine the factors that affect the teaching of this process to students. As a result, we reviewed different studies and drew comparisons of what similar factors may influence this process among students. Thus, we found four main factors: the readers themselves, the teacher's strategy, text, and the students' task during the instruction process. Many studies showed that reflective teaching can be used in different fields; language teaching, music, mathematics, etc. Therefore, we concluded that reflective teaching process can be used in teaching reading comprehension process. And after studying reading comprehension process thoroughly, we noticed that if these four factors of reading events (reader, strategy, text, and task) can be reflected during teacher's reflective teaching process (planning, acting, reflecting, and evaluating), it would be more beneficial for students' reading comprehension process. That is how we arrived at the RTMRC design presented here.

In terms of evaluation, four experts in the field all agreed that this instructional design was highly appropriate for the teaching and learning process. Based on the findings, it can be concluded that this RTMRC is beneficial for the English language teaching and learning process.

\section{Acknowledgements}

We would like to express our sincere thanks to the experts, Dr. Soe Than, Dr. Wai Wai Oo, Dr. Thida Wai, and Dr. Su Su Khine, for their cooperative responses and for imparting their expertise.

Anita Habók has been granted funding by the János Bolyai Research Scholarship of the Hungarian Academy of Sciences.

\section{References}

Akyol, A., Çakıroğlu, A., \& Kuruyer, H. G. (2014). A study on the development of reading skills of the students having difficulty in reading: enrichment reading program. International Electronic Journal of Elementary Education, 6(2), 199-212.

Ashwin, P., Boud, D., Coate, K., Hallett, F., Keane, E., Krause, K-L., Leibowitz, B., MacLaren, I., McArthur, J., McCune, V., \& Tooher, M. (2015). Reflective teaching in higher education. London: Paul Ashwin and Bloomsbury.

Babaei, M., \& Abednia, A. (2016). Reflective teaching and self-efficacy beliefs: Exploring relationships
September 2020, Volume 13, Issue 1, 127-138

in the context of teaching EFL in Iran. Australian Journal of Teacher Education, 41(9), 1-27. https:// doi.org/10.14221/ajte.2016v41n9.1

Baker, W., \& Boonkit, K. (2004). Learning strategies in reading and writing: EAP contexts. RELC Journal, 35(3), 299-328. https://doi. org/10.1177/0033688205052143

Borich, G. D. (2014). Effective teaching methods: research-based practice (8th ed.). New Jersey: Pearson Education. Inc.

Brookfield, S. D. (2017). Becoming a critically reflective teacher. San Francisco: Jossey-Bass.

Calderhead, J. (1989). Reflective teaching and teacher education. Teaching and Teacher Education, 5(1), 43-51. https://doi.org/10.1016/0742-051X(89)9 0018-8

Cirocki, A., \& Farrelly, R. (2016). Research and reflective practice in the EFL classroom: Voices from Armenia. Eurasian Journal of Applied Linguistics, 2(1), 31-56. https://doi.org/10.32601/ejal.460995

Clarke, P. A. (2008). Reflective teaching model: A tool for motivation, collaboration, self- reflection, and innovation in learning. Georgia Educational Research Journal, 5(4), 1-18.

Connors-Tadros, L. (2014). Definitions and approaches to measuring reading proficiency. Center on Enhancing Early Learning Outcomes, Conversational processes and causal explanation. 1-7.

Dennison, P. (2009). Reflective practice: The enduring influence of Kolb's Experiential Learning Theory. Compass: Journal of Learning and Teaching, (1), 1-6. Retrieved October 17, 2018, from https:// journals.gre.ac.uk/index.php/compass/article/ view/12/28

Dewey, J. (1933). How we think: A restatement of the relation of reflective thinking to the educative process. New York: D.C. Heath and Company.

Edwards, S. (2017). Reflecting differently. New dimensions: reflection-before-action and reflection-beyond-action. International Practice Development Journal, 7(1), Art No 2. https://doi. org/10.19043/ipdj.71.002

Fatemipour, H. (2013). The efficiency of the tools used for reflective teaching in ESL contexts. ProcediaSocial and Behavioral Sciences, 93, 1398-1403. https://doi.org/10.1016/j.sbspro.2013.10.051 
Farrell, T. S. C. (2007). Reflective Language Teaching: From Research to Practice. London: Continuum.

Fitrisial, D., Tan, E., \& Yusuf, Y. Q. (2015). Investigating metacognitive awareness of reading strategies to strengthen students' performance in reading comprehension. Asia Pacific Journal of Educators and Education, 30, 15-30.

Garzon, A. (2018). Unlicensed EFL teachers coconstructing knowledge and transforming curriculum through collaborative-reflective inquiry. Profile: Issues in Teachers' Professional Development, 20(1), 73-87. http://dx.doi. org/10.15446/profile.v20n1.62323

Ghilay, Y., \& Ghilay, R. (2015). ISMS: A new model for improving student motivation and self-esteem in primary education. International Electronic Journal of Elementary Education, 7(3), 383-398.

Gilbert, J. (2017). A study of ESL students' perceptions of their digital reading. The Reading Matrix: An International Online Journal, 17(2), 179-195.

Graves, K. (2002). Developing a reflective practice through disciplined collaboration. The Language Teacher, 26(7), 19-21.

Gustafson, K. L., \& Branch, R. (2002). Survey of instructional development models (4th ed.). Syracuse: Syracuse University, ERIC Clearinghouse on Information Resources.

Habók, A. (2012). Evaluating a concept mapping training programme by 10 and 13 year-old students. International Electronic Journal of Elementary Education, 4(3), 459-472.

Habók, A., \& Magyar, A. (2018a). The effect of language learning strategies on proficiency, attitudes and school achievement. Frontiers in Psychology, 8(2358), 1-8. DOI: 10.3389/fpsyg.2017.02358

Habók, A., \& Magyar, A. (2018b). Validation of a selfregulated foreign language learning strategy questionnaire through multidimensional modelling. Frontiers in Psychology, 9(1388), 1-11. DOI: 10.3389/fpsyg.2018.01388

Habók, A., \& Magyar, A. (2019). The effects of EFL reading comprehension and certain learningrelated factors on EFL learners'reading strategy use. Cogent Education, 6(1616522), 1-19. https:// doi.org/10.1080/2331186X.2019.1616522

Heilman, A. W., Blair, T. R., \& Rupley, W. H. (1986). Principles and practices of teaching reading. Columbus: Charles E. Merrill.

Hulsman, R. L., Harmsen, A. B., \& Fabriek, M. (2009). Reflective teaching of medical communication skills with DiViDU: Assessing the level of student reflection on recorded consultations with simulated patients. Patient Education and Counseling, 74(2), 142-149. http://dx.doi. org/10.1016/j.pec.2008.10.009

Huang, S. (2013). Factors affecting middle school students' reading motivation in Taiwan. Reading Psychology, 34(2), 148-181.

Joyce, B. M., Weil, M., \& Calhoun, E. (2015). Models of teaching (9th Edition), Boston: Pearson.

Käsper, M., Uibu, K., \& Mikk, J. (2018). Language teaching strategies' impact on third-grade students' reading outcomes and reading interest. International Electronic Journal of Elementary Education, 10(5), 601-610.

Kennedy-Clark, S., Eddles-Hirsch, K., Francis, T., Cummins, G., Ferantino, L., Tichelaar, M., \& Ruz, L. (2018). Developing pre-service teacher professional capabilities through action research. Australian Journal of Teacher Education, 43(9), 39-58. http://dx.doi.org/10.14221/ajte.2018v43n9.3

Khaki, N. (2014). Improving reading comprehension in a foreign language. Strategic Reader, 14(2), $186-200$

Kolb, D. (1984). Experiential learning: Experience as the source of learning and development. PrenticeHall: New Jersey.

Kusumawati, E., \& Widiati, U. (2017). The effects of vocabulary instructions on students' reading comprehension across cognitive styles in ESP. Journal of Education and Practice, 8(2), 175-184.

Lim, C. K., Eng, L. S., Mohamed, A. R., \& Ismail, M. (2018). Relooking at the ESL reading comprehension assessment for Malaysian Primary Schools. English Language Teaching, 11(7), 146-157.

Nguyen, L. D., \& Suppasetseree, S. (2016). The Development of an Instructional Design Model on Facebook Based Collaborative Learning to Enhance EFL Students' Writing Skills. The IAFOR Journal of Language Learning, 2(1), 48-66. https://doi.org/10.22492/ijll.2.1.04

Nordin, N. M., Rashid, S. M., Zubir, S. I. S. S., \& Sadjirin, R. 


\section{iejee $\approx$}

(2013). Differences in reading strategies: How ESL learners read. Procedia - Social and Behavioral Sciences, 90(October), 468-477.

Pacheco, Q. A. (2005). Reflective teaching and its impact on foreign language teaching. Actualidades Investigativas en Educación, 5(3), 1-19. https://doi.org/10.15517/aie.v5i3.9166

Paterson, C., \& Chapman, J. A. (2013). Enhancing skills of critical reflection to evidence learning in professional practice. Physical Therapy in Sport: Official Journal of the Association of Chartered Physiotherapists in Sports Medicine, 14(3), 133138. https://doi.org/10.1016/j.ptsp.2013.03.004

Pollard, A, Black-Hawkins, K., Hodges, G. C., Dudley, P., James, M., Linklater, H., Swaffield, S., Swann, M., Turner, F., Warwick, P., Winterbottom, M., \& Wolpert, M. A. (2014). Reflective teaching in schools (4th ed.). London: Bloomsbury Publishing Plc.

Rastegar, M., Kermani, E. M., \& Khabir, M. (2017). The Relationship between Metacognitive Reading Strategies Use and Reading Comprehension Achievement of EFL Learners. Open Journal of Modern Linguistics, 7(2), 65-74. https://doi. org/10.4236/ojml.2017.72006

Ratminingsih, N. M., Artini, L. P., \& Padmadewi, N. N. (2018). Incorporating self and peer assessment in reflective teaching practices. International Journal of Instruction, 10(4), 165-184.

Reiser, R. A., \& Dempsey, J. V. (2012). Trends and issues in instructional design and technology (3rded). USA: Pearson Education, Inc., Boston: Allyn \& Bacon.

Richards, J. (1990). Beyond training: approaches to teacher education in language teaching. Language Teacher 14(2), 3-8.

Richards, J. C., \& Lockhart, C. (2005). Reflective teaching in second language classrooms. New York: Cambridge University Press.

Richardson, V. (1990). The evolution of reflective teaching and teacher education. In $\mathrm{M}$. Pugach (Ed.). Encouraging Reflective Practice in Education (pp. 3-19). New York: Teachers College Press.

Schön, D. (1983). The reflective practitioner: How professionals think in action. NewYork: Basic Books.
Senge, P. (1990). The fifth discipline: The art and practice of the learning organisation. New York: Doubleday.

Snow, K. (2003). Reading for Understanding: Toward an $R \& D$ Program in Reading comprehension. Santa Monica: RAND Corporation. Retrieved October 20, 2018, from www.rand.org/publications/MR/ MR1465/)

Spalding, E., \& Wilson, A. (2002). Demystifying reflection: A study of pedagogical strategies that encourage reflective journal writing. Teachers College Record, 104, 1393-1421. https:// doi.org/10.1111/1467-9620.00208

Staden, S. V. (2010). Reading between the lines: Contributing factors that affect grade 5 learner reading performance. RELC Journal 44(1), 74-83.

Suwanto (2014). The effectiveness of the paraphrasing strategy on reading comprehension in Yogyakarta city. Journal of Literature, Languages, and Linguistics - An Open Access International Journal, 4, 1-7.

Taggart, G. L., \& Wilson, A. P. (2005). Becoming a reflective teacher. Promoting Reflective Thinking in Teachers: 50 Action Strategies. Thousand Oaks, CA: Corwin Press.

Walker, B. J. (2008). Diagnostic teaching of reading: techniques for instruction and assessment (6thed.). Upper Saddle River, N.J.: Pearson/ Merrill/Prentice Hall.

Widdowson, H. G. (2015). Teaching language as communication. Oxford: Oxford University Press.

Yang, X. (2016). Study on factors affecting learning strategies in reading comprehension. Journal of Language Teaching and Research, 7(3), 586590. http://dx.doi.org/10.17507/jltr.0703.21

Zhang, L., \& Zhang, L. J. (2013). Relationships between Chinese College Test takers' strategy use and EFL reading test performance: A structural equation modeling approach. RELC Journal, 44(1), 35-57. https://doi.org/10.1177/0033688212463272

Zhang, L. J. (2016). English language teaching today: linking theory and practice. In W. A. Renandya, \& H. P. Widodo (Eds.). English language teaching today. linking theory and practice (pp. 127-142). Switzerland: Springer International Publishing. 